\title{
POLISH SOCIOLOGICAL TRADITIONS AS AN INSPIRATION FOR A HISTORICAL APPROACH IN MANAGEMENT
}

\author{
Piotr Górski* http://orcid.org/0000-0002-4272-9225 \\ Tomasz Ochinowski** (ํ) http://orcid.org/0000-0001-8343-4071
}

\begin{abstract}
Background. The article draws readers' attention to the potential significance of works of selected Polish sociologists for the historical approach in Management and Organizational Studies (MOS). The reasons for the lack of interest in history, which is typical of management scholars (except for business historians), are outlined, and the phenomenon of "historical turn" in MOS as a counterpoint of the mentioned phenomenon is discussed.
\end{abstract}

Research aims. The central theme of the article is constituted by the thesis that the "historical turn" cognitively corresponds to the earlier conceptions which were developed by Kazimierz Dobrowolski. The article also highlights the internationally renowned works of Jerzy Zubrzycki and Aleksander Matejko, which are deeply rooted in the Polish historical experience.

Methodology. The analysis was based on studies of literature on the subject and the publication of selected sociologists.

Key findings. The article shows that that the works of mentioned sociologists offer an integral method assuming a holistic nature of social reality, postulating a combination of functional and historical approaches as well as the use of materials obtained through field research and document studies.

Keywords: organization studies, history, polish sociologists

JEL Codes: A14, N01, N80

* Faculty of Management, Department of Organizational Management, Human Resources and Economic Law, AGH University of Science and Technology, Krakow, Gramatyka 10, 30-067 Cracow, Poland. E-mail: pgorski@zarz.agh.edu.pl

${ }^{* * * *}$ Faculty of Management, Academic Unit for Managerial Psychology and Sociology, Academic Subunit for Organizational Sociology and Business History, University of Warsaw, Szturmowa 1/3, 02-678 Warsaw, Poland. E-mail: ochinto@wz.uw.edu.pl 


\section{INTRODUCTION}

The researchers might venture a thesis that a historical perspective has nearly always been present in social sciences such as economics, sociology or political science, especially when these sciences were shaping their distinctness in the $18^{\text {th }}$ and $19^{\text {th }}$ centuries. This was because, on the one hand, the reflection on the society, economy or politics was rooted in history, and also because these disciplines - in their modern form - developed in the context of creating a modern society, with its social structure different from the feudal one, type of economy, political system or type of personality. Slightly different is the case with management and organizational sciences. They were shaped in the environment of engineers at the turn of the $19^{\text {th }}$ and $20^{\text {th }}$ centuries in the positivist paradigm, which largely influenced the desire to formulate universal laws, principles and recommendations allowing for effective management of not only people's work but also the functioning of the organization. The representatives of institutional economics, for example Roland Coase or Oliver Williamson, have a much broader approach to the social context of management or, more generally, economic activity. However, proponents of the use of the historical perspective in organizational research generally treat neo-institutionalism as an ahistorical trend (Suddaby, Foster, \& Mills, 2014).

The structural \& functional trend, dominant from the middle of the $20^{\text {th }}$ century, was far from seeing the historical dimension in management and organizational sciences; it treated the organization in terms of an open system and called for analyzing the organization's relations with its surroundings, but was not interested in answering questions about the genesis of the present state. The psychologists and sociologists who pursued research reflection in the field of interpersonal relations did not apply the historical perspective either. By contrast, history was present in research on business history, institutionalized in the specific American conditions in which the earliest corporations began to emerge and strengthen their position. This sub-discipline developed at Harvard University. Published in 2003, the book Business History around the World (Amatori \& Jones, 2003) presents not only the development of this sub-discipline at the turn of the $20^{\text {th }}$ and $21^{\text {st }}$ centuries and its methodological problems but also the development of research carried out in the US, Western Europe, Asia and Latin America. 
The publications contained in this book also emphasize the importance of national conditions that, for example, make US researchers study corporations and their role in creating the concept of management, turn the attention of researchers in Mediterranean countries to family business, and in Japan - to the rapid economic development after World War II. The transformations of Polish enterprises and enterprise management processes might perhaps be of interest for Polish researchers as well as domestic and foreign readers.

This article, devoted to selected issues related to the use of the historical perspective for the needs of organizational research, goes beyond the scope of business history. The researcher point out material methodological concerns that are linked to a phenomenon located strictly within management sciences, i.e., the so-called "historical turn". The researcher focus on discussing a thesis that previous research ideas and practices, also developed by Polish representatives of social sciences, such as Kazimierz Dobrowolski - a central figure of our deliberations - Jerzy Zubrzycki and Aleksander Matejko, closely corresponded to the intellectual atmosphere of the mentioned turn.

\section{CHARACTERISTICS OF THE HISTORICAL PERSPECTIVE IN MANAGEMENT SCIENCES}

According to Michael Rowlinson and Charles Booth (Booth \& Rowlinson, 2006), since more or less the 1990s there has been a gradual, though ultimately quite radical, increase in interest in history among Western organization theorists and scientists dealing with related problem areas. This was associated with the fact that the researchers of the organizational reality turned their attention to the works on philosophy of history as well as with the more and more evident relationships between the issues of organizational culture and organizational memory. It is the area of research referred to as the "organizational culture" that has long been and to this day remains, not only in the opinion of the quoted authors, the natural intellectual space of "transfer" of the sciences about the past into the area of management (Górski, 2007b). The "historical turn" triggered off the still ongoing debate on the relationships between history and organizational theory as well as reflections on the style of writing about organizations in the historical perspective (Mills et al., 2016). The mentioned intellectual tendencies 
were a manifestation of a wider phenomenon in the management and organizational studies of the 1990s, i.e. the departure from doing research exclusively in the structural \& functional paradigm. This was related both to the perception and appreciation of the importance of culture in management, as The researcher have already hinted, and was the effect of global social changes, the growing significance of emancipation, racial and feminist movements, which were reflected in the analyses of management and organizational phenomena and processes from the female or ethnic perspective (Górski, 2007a).

The first decade of the $21^{\text {st }}$ century brought the institutionalization of organizational research that takes into account the historical perspective. As part of the annual European Group for Organizational Studies (EGOS) conference, one of the thematic groups was devoted to the historical perspective. Historians dealing with the organizational issues, Stephanie Decker, Christina Lubinski and Daniel Wadhwani, set up the Organizational History Network. Publications devoted to the use of the historical perspective appear not only in Organization and Management History but also in leading management and organization magazines: Organization, Organization Studies, Academy of Management Journal and Business History. Recently, noteworthy have not only been publications presenting the results of research but mainly papers on methodological issues. They are included in the book titled Organizations in Time: History, Theory, Methods (Bucheli \& Wadhwani, 2014) and in a special 2016 issue of the Academy of Management Review magazine. In line with the trends of the "historical turn", the relationship between historical research and organizational theory has turned into a dominant problem. Mairi Maclean, Charles Harvey and Stewart R. Clegg (2016) propose theoretical approaches that can be applied in historical organizational research.

The quoted British authors deploy arguments that are slightly distinct from the ones favored to date by the promoters of the application of a historical perspective in organizational research. Instead of emphasizing the advantages of applying the historical perspective in organizational research, they point - on the example of three theoretical concepts - to the benefits that historical organizational research can derive. These are: institutional entrepreneurship, evolutionism and historical evolutionism. They also refer to the studies in which they have been applied. Furthermore, they indicate the basic methodological principles that should be observed in such studies. The first one is dual 
integrity that consists in respecting the principles of both sub-disciplines - historical research and organizational theory. The second principle is pluralistic understanding based on researchers opening their minds to various research perspectives. It also results from the fact that business history should be perceived as an integrating sub-discipline, showing relationships not only in companies and between them but also between people, between the material and non-material, between the present and the past (Harvey \& Wilson, 2007).

The third principle was defined as representational truth. This principle calls for compatibility between the logic of evidence based on the collected material and the narrative containing the interpretation. It has been an important issue since the beginning of the debate on business history for, on the one hand, this sub-discipline referred to the theory of economics whose aim was to explain phenomena and processes, and, on the other hand, it was influenced by Weber's concept of understanding as it belongs to the humanities. Therefore, the authors place great emphasis on methodological self-awareness of researchers, expecting not only a balanced proportion between arguments and their interpretation but also the sensitivity to the specificity of each of them. The next principle applies to sensitivity to the contexts of studied phenomena (context sensitivity). Robin Collingwood highlighted this when he wrote, "no historical fact can be truly ascertained until The researcher have ascertained its relations with its context" (Collingwood, 1993, p. 419). This principle is perfectly in tune with the analysis of the longue durée processes promoted years ago by the representatives of the Annales School. The last principle is theoretical fluency that requires the researcher not so much to be flexible as to be able to combine theory and research or used concepts and their operationalizations as well as to move from details and what is complex to a simple and understandable narrative. For, as the authors claim, referring to Randall Morck and Bernard Yeung:

The inclination to theorize derives from a search for patterns and frameworks that allows particular events and phenomena to be seen in conjunction with other analogous circumstances and occurrences, enabling parallels and variations to be discerned in the trajectories of organizations across time and space and conclusions to be drawn accordingly (Maclean, Harvey, \& Clegg, 2017, p. 478). 


\section{BRIEF DESCRIPTION OF METHODOLOGICAL DIRECTIVES AND THEORETICAL CONCEPTS OF KAZIMIERZ DOBROWOLSKI}

The cognitive directives cited at the end of the previous point may evoke a sense of a kind of déjà vu for researchers who grew up in the tradition of Polish sociology. In the opinion of the authors of this paper, this is well exemplified by the works of the Kraków sociologist and ethnographer Kazimierz Dobrowolski (1894-1987), who was professionally active long before the "historical turn". In terms of methodology, these works offer an integral method assuming a holistic nature of social reality, postulating a combination of functional and historical approaches as well as the use of materials obtained through field research and document studies. At the theoretical level, the approach of the aforementioned scholar resulted in two propositions - the theory of historical background and the theory of spontaneous processes.

A close reading of Dobrowolski's works provides information that several decades ago he not only postulated but - more importantly implemented in his scientific papers the methodological suggestions indicated by the three British researchers mentioned above. The request for dual integrity was complied with based on historical studies completed by Dobrowolski at the Jagiellonian University as well as sociological and social anthropology programs in France and Great Britain. The scope of his scientific work included studies in the field of socio-economic history, history of science and culture, ethnography and sociology. Dobrowolski argued for the application of the integral approach also with regard to management and organizational sciences. Their core would be:

(...) not only those disciplines that are currently dealing with the discussed issues, such as management and organizational studies with their various directions, like economics, sociology or social psychology, but also the disciplines that shed light on non-social determinants of phenomena and processes of the science proposed above - in particular physical geography (...), biology, psychology. This integral science should naturally place the main emphasis on contemporary phenomena and processes; it would, however, have to include an outline of the development of various forms of organizational 
relationships, to start with the oldest socio-economic formations. Such an outline would reveal the dynamics of development of management and organization processes; it would show different forms of target groups, allow for capturing elements that recur and disappear in the historical development and, finally, would to a certain extent facilitate the understanding of the current reality (Dobrowolski, 1973, p. 32).

In his concept, Dobrowolski advocated the inclusion of disintegration and dysfunction processes. The spontaneous processes are shaped both on the historical background and as a result of spontaneous, unforeseen reactions that are a response to the actions of people who have power, also power in the organization, and establish formal and legal solutions. This demonstrates the need to consider knowledge provided not only by history but also by psychology and legal analysis. The spontaneous process analyzed by Dobrowolski is exemplified by migrations. When classifying the causes, course and effects of these processes, Dobrowolski draws attention to the need to use - based on the competence of a researcher or a team of researchers - knowledge in the field of demography, economics, history or sociology. Dobrowolski used the knowledge of post-war migrations in Poland in studies carried out as part of a research project involving industrial enterprises, devoted not only to the transformations of the social structure but also the cultural conditioning of people's behavior in the organization (Dobrowolski, 1966, pp. 111-195).

Important for the management issues were the studies devoted to the workers' self-government, in particular the presentation of dysfunctional phenomena in a socialist workplace as well as the development of new patterns of worker participation in enterprise management (Dobrowolski, 1973, pp. 134-140). Similarly as in the case of research on migration processes, the integral approach to these research issues was manifested by the use of a variety of research sources and methods, observations, interviews, press and statistical material analysis, as well as specialist studies.

According to Dobrowolski, an integral presentation of the studied reality requires the researcher to take the following actions (Dobrowolski, 1966, pp. 64-65):

a) Gather any and all, where possible, categories of sources that can secure the most comprehensive reproduction and explanation of the issues in question. 
b) Integrally exploit all research methods and techniques, as long as they are useful, purposeful and feasible and may contribute to the deepening and refining of the examined reality.

c) Detect any conditions affecting the formation of the examined reality, in particular non-social conditions.

d) Integrally recognize forces that trigger the dynamics of transformations with particular emphasis on the clashing of old and new elements, on the variability of forces impacting the processes, on the detection of leading forces and the ones that cause the emergence of processes of disharmony.

e) Strive to always view socio-cultural areas identified in the study in relation to other fields and processes.

f) Integrally detect all functions, both intentional and unintentional, of the studied institution.

g) Determine the historical position of a given reality in a larger developmental chain.

In turn, the theory of historical background shows the necessity of a pluralistic understanding of the studied phenomena, which involves the need to relate what The researcher currently observe to the phenomena and processes that precede and condition them, and thus understanding by reference to the genesis of the studied phenomena. In the opinion of the Kraków sociologist, this study is also of practical value. Getting to know the background not only allows for a better understanding of the present but for introducing changes as well. However, appreciating the importance of the historical background, Dobrowolski is not a determinist. He does not think that The researcher are determined or fated by the past, as best evidenced by the studies on the modification and changes in culture during the Renaissance. Dobrowolski believes that the study of the background is especially important at the time of historical breakthroughs, e.g. the period of post-war transformations (Dobrowolski, 1967, p. 48).

Also, the author of the "theory of spontaneous processes" drew researchers' attention to the method of presentation of knowledge obtained in the course of research. He demanded caution in generalizations resulting from comparisons. The examples from research to which he referred in his works were neither illustrative nor, all the more, anecdotal, but fulfilled the purpose of presenting a certain type of phenomena or processes. Research devoted to the processes of assimilation of cultural products can be a good illustration. The examples 
given serve to indicate different types of methods and ways of taking over these products, for example related to contacts with migrants' families or the work of peasant-workers. Dobrowolski also called for a constant reflection over the language in which researchers formulate their knowledge, believing that "the existing language quite considerably influences the researcher's cognitive process” (Dobrowolski, 1967, p. 69).

Finally, in his scientific work, Dobrowolski exhibits a clear context sensitivity, which results from the pluralistic nature of social reality. This is attested to by the following observation made in connection with surveys of families from the Małopolska region in Poland.

Based on the assumption that every social phenomenon, and thus also the functioning of a family, must be closely related to the historical context, I place a strong emphasis on the obligation to accurately characterize the basic conditions in the mentioned periods. This characteristic should cover both the principal (political, economic, social and cultural) conditions as well as local conditions related to a given settlement or region (Dobrowolski, 1967, p. 71).

Context sensitivity is closely related to the postulated integrity of the research approach, mutual complementation of research sources and methods - a postulate formulated later as a well-established theory (Konecki, 2000). Among these methods, however, special mention should - according to Dobrowolski - be made of field methods that allow for capturing a living reality which, if not recorded, will be destroyed or forgotten in the future (Dobrowolski, 1966, pp. 120-121).

The last postulate of British researchers was the expectation of theoretical fluency. In the case of the Kraków sociologist, it was not only a combination of functional and historical analyzes or the perception of relationships between various types of determinants resulting from the considered contexts. Due to the need to take into account different categories of phenomena and their different pace of variation, Dobrowolski required the researcher to combine the individualizing point of view with the generalizing one, to be able to merge individual, repetitive and homogeneous facts into adequate classes of phenomena. He was in favor of the inductive approach, stressing that the main goal of conducted research is to build explanatory theories. This purpose is successfully accomplished by historical analysis, as it not only provides material to formulate assertions (conclusions) but justifies these assertions as well (Dobrowolski, 1966, p. 202). Thinking in terms of functional analysis 
does not take into account the past as the initial situation. Therefore, especially in the study of breakthrough phenomena and processes, "each functional analysis of any current reality must be historical and developmental, even if it is narrowed down to an initial situation with a limited time horizon" (Dobrowolski, 1966, p. 202). This approach is best illustrated in the studies of determinants of the diversity of social processes taking place in the towns of the Central Industrial District lying on both sides of the Vistula river.

\section{ORGANIZATIONAL SOCIOLOGY AS A "LINK" BETWEEN HISTORY AND MANAGEMENT AS EXEMPLIFIED BY THE WORKS OF JERZY ZUBRZYCKI AND ALEKSANDER MATEJKO}

It is worthwhile seeing Dobrowolski's thought in the context of the use of sociology as a field building "intellectual bridges" between history and organizational sciences, as illustrated by the traditions of social sciences also in our country. One of the spectacular Polish achievements in this domain is the concept of cross-cultural management, which was developed by a historian and sociologist Jerzy Zubrzycki (1920-2009) for the Australian government. The solutions proposed by the aforementioned student of Florian Znaniecki (1882-1958) resulted in the development of one of the few effective multicultural programs in the world (the program was implemented until the end of the 1990s). This program was based on the assumption that modern societies are increasingly integrated by everyday interdependence, division of labor and common everyday experiences rather than by historical tradition, religion or ethnic origin. Hence, conditions conducive to the integration of immigrants are such factors as the possibility of speedy acquisition of civil rights by immigrants, state aid in learning a language and gaining qualifications, an open system of education and promotion of respect for various traditions. At the same time, the administration of the country of settlement requires immigrants to strictly comply with the principle of equality of civic rights and obligations and the duty for every citizen to actively participate in the life of the country (e.g., Zubrzycki, 1986; Pakulski, 2011). Zubrzycki openly declared that he based his program of public management of 
multiculturalism directly on the experiences of Jagiellonian Poland (Pakulski, 2011). Thus, The researcher can talk about an example of history used for the needs of organizational practice.

Zubrzycki had also "caught the history hot" by strict sociological studies. In doctoral thesis, which was prepared under Florian Znaniecki supervision in 1954, he explored the social and demographic changes in Poland affected by Communist regime. But the main topic of Zubrzycki's research activity were connected with emigrants issues. Initially, he was studying the processes of adaptation of Polish refugees to the social situation in Great Britain, and then, still following his personal situation, he directed his research point of interest to the next waves of emigrants to Australia. The statistic and autobiographical data were combined in these studies to establish the processual frame for multicultural Governance. Zubrzycki's research has revealed the concept of multiculturalism, consistent with the tradition of Durheim, as "a philosophy and policy of effectively managing integration, the goal of which is the minimizing of anomie. The concern with building a well-integrated and cohesive society around a pluralist cultural framework was paramount" to Polish- Australian scholar (Babiński, Dulczewski, \& Szczepański, 1998; Naraniecki, 2013, p. 247).

The "architect of multicultural Australia" - to borrow a somewhat pompous byname that John Hartwell Williams and John Bond bestowed upon Zubrzycki (Williams \& Bond, 2013) - referred to history also in his other texts and sociological addresses, especially noting the importance of history of industrialization for comprehending modern times (e.g. Zubrzycki, 1983). In the article "Academic ethos in the New Dark Age" (Zubrzycki, 1997, p. 30), which fits into the still pending debate on the condition of the university, Zubrzycki imposed on university lecturers, among others, the obligation to remind "students (...) and the public at large that understanding and profound knowledge of the past is as important as the desire to have a better future". A few years ago, Jan Pakulski (2011), the successor of the cited researcher among Australian sociologists, suggested that this multicultural program rooted in the Polish historical experience may be valid for our country today. Yet, this remark has not been taken up to date by scientists nor by practitioners of public life.

However, it fits into the works of another Polish sociologist who spent most of his life as an emigrant. The person in question in Aleksander Matejko (1924-1991), a participant in the famous seminars 
of Stanisław Ossowski (1897-1963) and the author of an interesting version of modern organizational sociology practiced in Poland in the 1950s and 1960s relatively regardless of ideological pressures and in close liaison with Western research. After electing to emigrate (in 1968), the sociologist gained an international scientific and expert position, above all as a professor at the University of Alberta (Canada). Indirectly, without making a direct reference to Zubrzycki, Matejko showed that the traditions close to the author of the multicultural program for Australia were forgotten in post-war Poland. "Civic culture - he wrote - which has developed on the basis of the opposition against the Communist establishment does not necessarily fit well into the problems and needs of a pluralistic arrangement" (Matejko, 1991, p. 93). The quoted organizational sociologist thus indicated the long-term role - also as a burden - of historical experience in organizational analysis (Bugajewski, 2010). To overcome them, Matejko proposed ways to "rehabilitate" the societies of Central and Eastern Europe, such as formal institutionalization carried out in accordance with a democratic ethos, promotion of informal group engagement and reorientation of motivation based on the worldview, which he called spiritual. It is worth treating the mentioned levels of socio-technics recommended by the Polish-Canadian sociologist as the dimensions of historical analysis of the society in the context of challenges of public management. After 1990, Matejko came to Poland several times. He left a kind of "substantive testament" for the practitioners of organizational life in the form of a publication (with manuscript rights) of Socjotechnika zarzqdzania [Socio-technics of Management] (Matejko, 1994).

The interest in Socio-technic (as a kind of non-manipulative social engineering) Matejko borrowed from Adam Podgórecki (1925-1998), the most famous sociologist among Polish scholars who lived in Canada at last. Podgórecki's contribution to historical approach in management needs a separate study in future. In this article, the authors only signal the work of Matejko, who in the circle of Podgórecki (they worked quite closely with each other in Poland) was particularly concerned with organizational issues. 


\section{CONCLUSION}

A brief description of Dobrowolski's methodological and theoretical concepts allows for emphasizing that the methodological postulates listed by contemporary British researchers - connected with the application of a historical perspective in management and organizational studies were taken into account in the previous studies of the Kraków sociologist. This fact was highlighted not so much with an intention to prioritize it when recommendations are put forward but only to draw attention to their apparently obvious connection with the conduct of interdisciplinary research aimed at showing the genesis of phenomena observed today. His proposal expressed in the theory of spontaneous processes and in the theory of historical background, as well as detailed studies on folk culture, social thought or migration, demonstrate the value of this type of research of phenomena during breakthrough periods. The author of the theory of spontaneous processes considered the period of post-war changes, migration to the Western Territories, industrialization and transformations of peasant and workers culture to be breakthrough times.

The possibilities of using the sociological thoughts of Dobrowolski, Zubrzycki and Matejko as an inspiration for the development of the historical approach in Polish management sciences may seem trivial. The point is, however, that the legacy of the first of the listed authors has not been associated with the "historical turn", the achievements of the second scholar have been almost completely forgotten (despite their evidently significant importance for the managerial practice), while the works of the third scientist have so far been interpreted exclusively in the structural \& functional context, to which the author himself admitted openly in his works created before the emigration period. In this text, the researcher therefore propose to start a debate on the possibilities to recapture the organizational past through relatively new interpretations of the scientific work of the three grand old men of Polish organizational sociology. Whether or not reaching for this past is material for management in Poland requires a separate discussion. Our position is expressed in this article.

From historical point of view, the separate cognitive question is constituted by the fact, that Dobrowolski, Zubrzycki and Matejko were developing their research in three different contexts, Communist 
Poland, university sphere and state administration in Australia and "sterile environment of Canadian academic bureaucracies" as the anonymous reviewer of this article pointed out. The impact of these modes to research practice is very interesting matter, however, exceeding the assumptions of the presented article.

The authors of this article believe that nowadays, living in another breakthrough era associated with the Polish post-communist transformation and participation in the globalized economy, Polish management and organization researchers should - more often than they have to date - apply a historical approach that takes into account the pluralistic dimension of the organization's surroundings and the various pace of its transformation. For the implementation of such cognitive activities, the inspirations drawn from the work of Kazimierz Dobrowolski may prove helpful and, at the same time, interesting for foreign recipients, as has been the case with the later ideas of Zubrzycki and Matejko and, above all, with organizational practices that these ideas led to.

\section{References}

Amatori, F. \& Jones, G. (2003). Business History around the World. Cambridge: Cambridge University Press.

Babiński, G., Dulczewski, Z. \& Szczepański, J. (1998). Sprawozdania i informacje. Opinie o działalności i dorobku naukowym prof. Jerzego Zubrzyckiego. Ruch Prawniczy, Ekonomiczny i Socjologiczny, 3-4, 487-493.

Booth, Ch. \& Rowlinson, M. (2006). Management and organizational history: Prospects. Management and Organizational History, 1, 5-30.

Bucheli, M. \& Wadhwani, R.D. (2014). Organizations in Time: History, Theory, Methods. Oxford: Oxford University Press.

Bugajewski, M. (2010). Świadectwo historiografii. In: J. Kolbuszewska, R. Stobiecki (red.). Historyk wobec źródet. Historiografia klasyczna i nowe propozycje metodologiczne (pp. 107-114). Łódź: WN Ibidem.

Collingwood, R. (1993). The Idea of History. Oxford: Oxford University Press.

Dobrowolski, K. (1966). Studia nad życiem społecznym i kultura. Prace Komisji Socjologicznej PAN oddział w Krakowie. Wrocław-Warszawa-KrakówGdańsk: Wyd. Ossolineum.

Dobrowolski, K. (1967). Studia z pogranicza historii $i$ socjologii. Prace Komisji Socjologicznej PAN oddziat w Krakowie. Wrocław-Warszawa-Kraków-Gdańsk: Wyd. Ossolineum. 
Dobrowolski, K. (1973). Teoria procesów żywiołowych w zarysie. Prace Komisji Socjologicznej PAN oddziat w Krakowie. Wrocław-Warszawa-Kraków-Gdańsk: Wyd. Ossolineum.

Górski, P. (2007a). „Management and Organizational History” nowe czasopismo w dziedzinie organizacji i zarządzania. Organizacja i Kierowanie, 2, 141-151.

Górski, P. (2007b). Perspektywa historyczna w teorii i badaniach w dziedzinie organizacji i zarządzania. Współczesne Zarzązanie, 4, 20-29.

Harvey, C. \& Wilson, J. (2007). Redefining business history: An editorial statement. Business History, 49, 1-7.

Konecki, K. (2000). Studia z metodologii badań jakościowych. Teoria ugruntowana. Warszawa: WN PWN.

Maclean, M., Harvey, Ch. \& Clegg, S. (2016). Conceptualizing historical organization studies. Academy of Management Review, 41(4), 609-632.

Maclean, M., Harvey, Ch. \& Clegg, S. (2017). Organization theory in business and management history: Present status and future prospects. Business History Review, 91(3), 457-481.

Matejko, A. (1991). Civic culture and consumption in Eastern Europe. Sociologia Internationalis, 29, 75-102.

Matejko, A. (1994). Socjotechnika zarzqdzania. Szczecin: Wyd. ZSB.

Mills, A.J., Suddaby, R., Foster, W.M. \& Durepos, G. (2016). Re-visiting the historic turn 10 years later: Current debates in management and organizational history - An introduction. Management \& Organizational History, 2, 67-76.

Naraniecki, A. (2013). Zubrzycki and multicultural governance in Australia. Journal of Intercultural Studies, 3, 246-261.

Pakulski, J. (2011). Polskość jagiellońska w Australii. Więź, 4, 46-54.

Suddaby, R., Foster, W. \& Mills, A.J. (2014). Historical institutionalism. In: M. Bucheli, D. Wadhwani (eds.). Organizations in Time: History, Theory, Methods (pp. 100-123). Oxford: Oxford University Press.

Williams, J.H. \& Bond, J. (2013). The Promise of Diversity: The Story of Jerzy Zubrzycki, Architect of Multicultural Australia. Toorak, Vic.: Grosvenor Books. [Polish translation: J.H. Williams \& J. Bond (2016). Jerzy Zubrzycki: wielki Polak i Australijczyk. Tłum. J. Nurmis. Warszawa: Neriton].

Zubrzycki, J. (1983). Man in industrial civilization. Australian Journal of Forensic Sciences, 15(3), 140-146.

Zubrzycki, J. (1986). Multiculturalism and beyond: The Australian experience in retrospect and prospect. Journal of Ethnic and Migration Studies, 13(2), 167-176.

Zubrzycki, J. (1997). Academic ethos in the New Dark Age. Australia \& World Affairs, 33, 21-30. 